\title{
Peran Dinas sosial Kabupaten Bone dalam Menanggulangi kemiskinan (Perspektif Undang-Undang nomor 11 Tahun 2009 Tentang Kesejahteraan Sosial)
}

\author{
Heryanti \\ Institut Agama Islam Negeri (IAIN) Bone \\ Heryanti1998@gmail.com
}

\begin{abstract}
Abstrak
Tujuan dari penelitian ini adalah (1) Untuk mengetahui peran Dinas Sosial Kabupaten Bone dalam menanggulangi kemiskinan Perspektif Undang-Undang Nomor 11 Tahun 2009 tentang Kesejahteraan Sosial; (2) Untuk mengetahui kendala yang dihadapi oleh Dinas Sosial Kabupaten Bone dalam menanggulangi kemiskinan.Metode yang digunakan dalam penelitian ini adalah penelitian lapangan dengan pendekatan yuridis empiris yang menggunakan sumber data primer dan sumber data skunder yang terdiri dari bahan hukum primer, bahan hukum skunder dan bahan hukum tersier. Adapun teknik pengumpulan data yakni dengan cara melakukan wawancara dan melakukan studi dokumen kepustakaan yang erat kaitannya dengan objek yang diteliti, kemudian dianalisis dengan cara kualitatif dengan menggunakan metode deduktif. Hasil penelitian ini menunjukkan bahwa Dinas Sosial Kabupaten Bone telah melaksanakan perannya dalam penanggulangan kemiskinan di Kabupaten Bone berdasarkan Undang-Undang Nomor 11 Tahun 2009 tentang Kesejahteraan Sosial namun belum optimal, hal ini dapat dilihat dari meningkatnya angka kemiskinan di Kabupaten Bone setiap tahunnya.Adapun kendala yang dihadapi oleh Dinas Sosial Kabupaten Bone dalam menanggulangi kemiskinan yakni kurangnya anggaran daru pemerintah, kurangnya sumber daya manusia dan tingginya angka kemiskinan.
\end{abstract}

Kata Kunci: Peran Dinas sosial dan Undang-Undang nomor 11 Tahun 2009

Tentang Kesejahteraan Sosial

\section{PENDAHULUAN}

Kemiskinan pada hakekatnya merupakan persoalan klasik yang telah ada sejak keberadaan umat manusia. Hingga saat ini belum ditemukan suatu rumusan maupun formula penanganan kemiskinan yang dianggap paling jitu dan sempurna. 
Tidak ada konsep tunggal tentang kemiskinan. Strategi penanganan kemiskinan masih harus terus dikembangkan. Terdapat banyak sekali teori dalam memahami kemiskinan. ${ }^{67}$

Di Indonesia, masalah kemiskinan merupakan masalah sosial yang senantiasa relevan untuk dikaji terus menerus. Ini bukan saja karena masalah kemiskinan telah ada sejak lama dan masih hadir di tengah-tengah masyarakat saat ini, melainkan karena kini gejalanya semakin meningkat sejalan dengan krisis multidimensional yang masih dihadapi bangsa Indonesia. ${ }^{68}$

Terciptanya masyarakat yang adil dan makmur sebagaimana tercantum dalam alinea keempat UUD 1945 merupakan cita-cita mulia bangsa Indonesia sejak awal kemerdekaan. Program-program pembangunan yang dilaksanakan selama ini selalu memberikan perhatian besar terhadap upaya pengentasan kemiskinan karena pada dasarnya pembangunan yang di lakukan bertujuan untuk meningkatkan kesejahteraan masyarakat. Meskipun demikian, masalah kemiskinan sampai saat ini terus menerus menjadi masalah yang berkepanjangan. Kemiskinan merupakan masalah dalam pembangunan yang bersifat multidimensi karena dalam menanggulanginya, bukan saja terbatas pada hal-hal yang menyangkut hubungan sebab akibat timbulnya kemiskinan tetapi melibatkan juga prefensi, nilai dan politik. ${ }^{69}$

\footnotetext{
${ }^{67}$ Edi Suharto, Membangun Masyarakat Memberdayakan Rakyat, (cet.3; Bandung: PT. Refika Aditama, 2009)h.138

${ }^{68}$ Edi Suharto, Membangun Masyarakat Memberdayakan Rakyat, h.131

${ }^{69}$ Ali Khomsan dkk, Indikator Kemiskinan dan Mengklasifikasi Orang Miskin, (cet.1; Jakarta: Fakultas Ekologi manusia IPB bekerja sama dengan Yayasan Pustaka Obor Indonesia, 2015) h.1
} 
48 | Peran Dinas Sosial Kabupaten Bone

Begitupun dalam Al-quran dijelaskan tentang kemiskinan jauh berabad-abad silam sebagai bagian dari misi revolusi masyarakat arab yang terjebak dalam jurang ketimpangan antara yang kaya dengan yang miskin. Kemiskinan dianggap sebagai petaka, sehingga bagi mereka yang berada dalam garis kemiskinan hanya dijadikan sebagai masyarakat yang marginal dan pantas dijadikan sebagai budak belaka. Bahkan diantara mereka ada yang rela mengubur buah hatinya karena takut menjadi miskin. Dalam menjelaskan konsep kemiskinan Al-quran biasa menggunakan kata fakir yang disebutkan sebanyak 14 kali dan kata miskin yang disebutkan sebanyak 23 kali. $^{70}$

Krisis ekonomi di Indonesia yang terus berlangsung dari tahun 1997 telah menimbulkan paradigma restoratif, pengentasan, dan penanggulangan kemiskinan. Tingkat pertumbuhan ekonomi yang tinggi di Indonesia yang berlangsung sekitar 30 tahun berhasil menurunkan angka kemiskinan absolut secara signifikan. Mulai tahun 1970-an hingga awal 1990-an, angka kemiskinan berhasil diturunkan sebesar 50 persen. Namun, sejak krisis berlangsung mulai pertengahan 1997, angka kemiskinan naik dua kali lipat, sehingga menghapus prestasi tersebut, dan membuat upaya pengentasan penanggulangan kemiskinan kembali menjadi sesuatu yang mendesak untuk dilaksanakan dengan serius. $^{71}$

Kemiskinan terjadi karena beberapa faktor, bukan hanya faktor ekonomi, seperti masalah pendapatan, tetapi meliputi faktor sosial antara lain pendidikan,

\footnotetext{
${ }^{70}$ Syaiful Ilmi, Konsep Pengentasan Kemiskinan Perspektif Islam, Al-Maslahah, Vol. 13, No. 1, April 2017. h. 72-74

${ }^{71}$ Ilham Gemiharto dan Evi Rosfiantika, Tata Kelola Pemerintahan dalam Penanggulangan Kemiskinan Melalui Dana Hibah dan Bantuan Sosial Di Indonesia, Ilmu Politik dan Komunikasi, Vol.7, No.1, Juni, 2017, h.104
} 
kesehatan, ketenagakerjaan dan ketahanan pangan. Kemiskinan merupakan masalah mendasar yang menjadi pusat perhatian dunia. Langkah nyata saat ini adalah menyepakati asumsi dan kriteria kemiskinan serta melakukan perbaikan database kemiskinan agar tercipta persamaan persepsi dan konsep tentang kemiskinan secara universal. $^{72}$

Secara umum konsep kemiskinan dibagi menjadi dua yaitu kemiskinan absolut dan kemiskinan relatif. Kemiskinan absolut adalah kelompok masyarakat yang berada di bawah Garis Kemiskinan Daerah (GKD). Artinya kelompok masyarakat tersebut belum mampu memenuhi standar kebutuhan minimumnya yaitu sandang, pangan, pendidikan dan kesehatan. Untuk kemiskinan relatif diukur berdasarkan 2 pendekatan antara lain pendekatan moneter dan non moneter. Kemiskinan relatif ditentukan berdasarkan ketidakmampuan untuk mencapai standar yang telah ditetapkan oleh masyrakat setempat sehingga proses penetuannya sangat subyektif. ${ }^{73}$

Kabupaten Bone merupakan salah satu daerah yang memiliki tingkat kemiskinan masih di atas garis kemiskinan provinsi dan pusat. Berbagai langkah strategis pemerintah daerah untuk mendukung upaya penanggulangan kemiskinan tersebut melalui intervensi program/kegiatan secara terintegrasi antar lembaga pemerintah, swasta dan masyarakat. ${ }^{74}$

Data kemiskinan di Kabupaten Bone pada tahun 2015 sebanyak 60.603, pada tahun 2016 sebanyak 90.759 dan tahun 2017 sebanyak 92.010. dapat dilihat

\footnotetext{
${ }^{72}$ Rencana Kerja Pemerintah Daerah (RKPD) Kabupaten Bone Tahun 2015, h.38

${ }^{73}$ Rencana Kerja Pemerintah Daerah (RKPD) Kabupaten Bone Tahun 2015, h.38

${ }^{74}$ Harum A.Hamid, Kasubag. Program Dinas Sosial, wawancara oleh penulis di Kantor Dinas Sosial Kabupaten Bone, 9 Oktober 2018
} 
50 | Peran Dinas Sosial Kabupaten Bone

bahwa angka kemiskinan di Kabupaten Bone setiap tahunnya mengalami peningkatan, peningkatan yang paling signifikan terlihat pada tahun 2016, sementara pada tahun 2017 angka kemiskinan di Kabupaten Bone juga mengalami sedikit peningkatan. $^{75}$

Dalam Undang-Undang Nomor 11 Tahun 2009 tentang Kesejahteraan Sosial pada Pasal 29 huruf C menegaskan bahwa salah satu tanggung jawab pemerintah Kabupaten/Kota yaitu memberikan bantuan sosial sebagai stimulan kepada masyarakat yang menyelenggarakan kesejahteraan sosial. ${ }^{76}$

Berdasarkan hal tersebut, Dinas Sosial Kabupaten Bone telah melaksanakan program tersebut dengan tujuan mengurangi angka kemiskinan, program tersebut seperti bimbingan sosial dan pemberian bantuan, baik yang sifatntya produktif dalam hal ini yang masih mampu bekerja maupun konsumtif bagi masyrakat yang sudah tidak mampu bekerja. ${ }^{77}$

Berdasarkan survei yang dilakukan oleh calon peneliti di 3 Kecamatan yaitu Kecamatan Ponre, Kecamatan Awangpone dan Kecamatan Barebbo. Di Kecamatan Ponre,seorang pendamping desa atas nama Murniati yang mengatakan "Dinas Sosial telah melaksanakan tanggung jawab tersebut akan tetapi belum tepat sasaran, masyarakat yang diketegorikan sebagai warga miskin tidak menerima bantuan apapun justru sebaliknya yang menerima bantuan yang masuk kategori mampu". Di

\footnotetext{
${ }^{75}$ Harum A.Hamid, Kasubag. Program Dinas Sosial, wawancara oleh penulis di Kantor Dinas Sosial Kabupaten Bone, 9 Oktober 2018

${ }^{76}$ Republik Indonesia, "Undang-Undang Nomor 11 Tahun 2009 Tentang Kesejahteraan Sosial", Bab V, Pasal 29C

${ }^{77}$ Harum A.Hamid, Kasubag. Program Dinas Sosial, wawancara oleh penulis di Kantor Dinas Sosial Kabupaten Bone, 30 Oktober 2018
} 
Kecamatan Awangpone, Kasnaeni dan di Kecamatan Barebbo, Dawiah mengatakan“program yang dilaksanakan oleh Dinas Sosial Kabupaten Bone tidak tepat sasaran". 78

Penyebab program-program yang dilaksanakan oleh Dinas Sosial Kabupaten Bone tidak tepat sasaran antara lain karena pemerintah masih menggunakan data sensus penduduk yang belum diperbaharui. Selain itu, adanya kedekatan hubungan antara kader yang mendata dengan masyarakat juga menjadi salah satu penyebab bantuan sosial tidak tepat sasaran. Dalam hal ini petugas akan menjadikan masyarakat yang memiliki hubungan dekat dengan mereka sebagai kader pemberdayaan masyarakat dan mengabaikan maayarakat kurang mampu yang seharusnya menjadi penerima bantuan sosial. ${ }^{79}$

Berdasarkan dari uraian di atas, maka penulis tertarik untuk mengkaji lebih jauh tentang peran Dinas Sosial dalam menanggulangi kemiskinan di Kabupaten Bone perspektifUndang-Undang Nomor 11 Tahun 2009 tentang Kesejahteraan Sosial. Hal ini dilakukan untuk mengetahui peran Dinas Sosial dalam menanggulangi kemiskinan, apakah penanggulangan kemiskinan sudah sesuai dengan ketentuan yang termaktub dalam Undang-Undang Nomor 11 Tahun 2009 tentang Kesejahteraan Sosial atau belum.Berdasarkan dari latar belakang di atas, maka masalah pokok dalam penelitian ini adalah bagaimana eksistensi peran Dinas Sosial Kabupaten Bone dalam menanggulangi kemiskinan perspektif Undang-Undang Nomor 11 Tahun 2009 tentang Kesejahteraan Siosial. Merujuk pada pokok masalah ini, terdapat beberapa sub masalah yang dijabarkan dalam bentuk pertanyaan sebagai

\footnotetext{
${ }^{78}$ Murniati, Kasnaeni dan Dawiah, wawancara oleh penulis, 9 Oktober-11 Oktober 2018.

${ }^{79}$ Murniati, Kasnaeni dan Dawiah, wawancara oleh penulis, 9 Oktober-11 Oktober 2018.
} 
52 | Peran Dinas Sosial Kabupaten Bone

berikut Bagaimana peran Dinas Sosial dalam menanggulangi kemiskinan di Kabupaten Bone perspektif Undang-Undang Nomor 11 Tahun 2009 tentang Kesejahteraan Sosial dan apa kendala yang dihadapi Dinas Sosial Kabupaten Bone dalam menanggulangi kemiskinan.

\section{TINJAUAN PUSTAKA}

Dalam penelitian ini, penulis membutuhkan sumber bacaan dan penelitian sebelumnya yang dapat dijadikan sebagai bahan rujukan dan perbandingan dengan judul skripsi yang akan dikaji oleh peneliti. Sumber bacaan yang dimaksud adalah sumber bacaan yang berupa karya ilmiah yang telah ada sebelumnya dan buku-buku yang yang memiliki korelasi dengan masalah yang penulis angkat sehingga dapat memberikan gambaran tentang sasaran penelitian yang akan dipaparkan dalam penelitian ini, antaranya:

Penelitian terdahulu yaitu hasil penelitian yang ditulis oleh Dasril Arifin pada tahun 2013 Mahasiswa Fakultas Ekonomi Dan Ilmu Sosial Universitas Islam Negeri Sultan Syarif Kasim Pekanbaru dalan bentuk skripsi yang berjudul Peran Dinas Sosial terhadap Penanggulangan Angka Kemiskinan di Kabupaten Siak ( Studi kasus di Kecamatan Sei Mandau ). Dalam penelitian ini disimpulkan bahwa Pembangunan merupakan suatu proses untuk meningkatkan taraf hidup masyarakat, bangsa dan negara menjadi lebih baik dari sebelumnya baik secara fisik maupun non fisik. Berbagai pembangunan dari segi fisik telah di lakukan oleh pemerintah mulai dari pusat hingga ke daerah-daerah bahkan sampai ke desadesa. Namun, pembangunan dari segi non fisik berupa pembangunan sumber daya manusia (SDM) bagi 
masyarakat secara merata masih dapat di kategorikan belum terlaksana secara optimal.

Berdasarkan hasil penelitian di atas yaitu tentang peran dinas sosial dalam mengentaskan kemiskinan dapat di simpulkan yaitu: Usia responden atau keluarga miskin di kecamatan Sei Mandau yaitu mayoritas berusia 30-39 tahun atau usia produktif masyarakat dan juga di ikuti oleh tingkat pendidikan masyarakat yang manyoritas berpendidikan SD/tidak tamat SD, hal ini lah yang juga merupakan salah satu penyebab masyarakat kecamatan Sei Mandau berekonomi kelas menengah kebawah. Pekerjaan masyarakat yang mayoritas petani juga mengakibatkan masyarakat berekonomi kelas bawah karena pekerjaan responden berpengaruh terhadap pendapatan masyarakat, dan juga tanggungan keluarga yang besar. ${ }^{80}$

Perbedaan penelitian yang dilakukan oleh Dasril Arifin dengan penelitian yang dilakukan oleh peneliti yakni penelitian skripsi ini, fokus utamanya pada peran Dinas Sosial dalam penanggulangan kemiskinan dalam bidang ekonomi. Sedangkan penelitian yang dilakukan oleh penelititi yakni peran Dinas Sosial dalam menanggulangi kemiskinan berdasarkan Undang-Undang Nomor 11 Tahun 2009.

Penelitian yang dilakukan oleh Hikmah Wati pada tahun 2016 Mahasiswa Hukum Universitas Lampung Bandar Lampung dalam bentuk skripsi yang berjudul Peran Dinas Sosial Dalam Penyaluran Bantuan Sosial Sebagai Upaya Penanggulangan Kemiskinan Perkotaan Di Provinsi Lampung. Dalam penelitian ini disimpulkan bahwa Berdasarkan hasil penelitian tentang 3 masalah pokok di atas dan analisis hasil penelitian dapat diambil kesimpulan sebagai berikut: Pertama, Peran

\footnotetext{
${ }^{80}$ Dasril Arifin, Peran Dinas Sosial Terhadap Penanggulangan Angka Kemiskinan di Kabupaten Siak (Studi kasus di kecamatan Sei Mandau), (Skripsi Program Strata 1 Fakultas Ekonomi dan Ilmu Sosial Universitas Islam Negeri Sultan Syarif Kasim Pekanbaru,2013), h.68
} 
54 | Peran Dinas Sosial Kabupaten Bone

dinas sosial dalam penyaluran bantuan sosial terhadap fakir miskin perkotaan di Provinsi Lampung adalah sebagai representasi asas dekonsentrasi dan tugas pembantuan dari pemerintah pusat (Kementrian Sosial RI) kepada pemerintah daerah (Dinas Sosial) dengan fungsi perumusan, penyelenggaraan, pembinaaan dan pelaksanaan bantuan sosial di Provinsi Lampung dengan pendekatan Kelompok Usaha Bersama (KUBE). Kedua, Faktor penghambat dalam pelaksanaan penanggulangan penyaluran bantuan terhadap fakir miskin perkotaan di Provinsi Lampung ada 2 diantaranya: Minimnya pengetahuan kelompok KUBE di Provinsi Lampung dalam pembuat rekening untuk kepentingan bersama yang menghabiskan waktu cukup lama dan Bahasa, terkadang saat sosialisasi dan evaluasi seksi pemberdayaan fakir miskin Dinas Sosial Provinsi Lampung mengalami kesulitan interaksi dengan anggota KUBE karena mereka terkadang masih sering menggunakan bahasa suku atau bahasa daerah masing-masing. ${ }^{81}$

Perbedaan penelitian yang dilakukan oleh Hikmah Wati dengan penelitian yang dilakukan oleh peneliti yakni fokus utama penelitian skripsi ini, yakni pada penyaluran bantuan sosial di Perkotaan, sedangkan penelitian yang dilakukan oleh peneliti lebih menekankan pada eksistensi Dinas Sosial dalam penanggulangan Kemiskinan.

\footnotetext{
${ }^{81}$ Hikmah Wati, Peran Dinas Sosial dalam Penyaluran Bantuan Sosial Sebagai Upaya Penanggulangan Kemiskinan Perkotaan di Provinsi Lampung, (Skripsi strata 1 Fakultas Hukum Universitas Lampung Bandar Lampung, 2016). h.65
} 


\section{METODE PENELITIAN}

Sebagaimana diketahui bersama bahwa karya tulis ilmiah selalu ditopang oleh beberapa metode baik dari pengumpulan data maupun dari pengolahannya seperti dalam penyusunan skripsi ini dipergunakan sebagai berikut :

1. Jenis Penelitian dan Pendekatan Penelitian

Jenis penelitian yang digunakan berdasarkan karakteristik masalah yang diteliti, maka jenis penelitian yang digunakan adalah penelitian lapangan dengan mengumpulkan dan menganalisis data berupa kata-kata (lisan maupun tulisan) dan perbuatan-perbuatan manusia. ${ }^{82}$ Penelitian lapangan bertujuan untuk mendapatkan pemahaman yang mendalam tentang masalah-masalah manusia dan sosial dengan menginterpretasikan bagaimana makna tersebut memengaruhi perilaku mereka, bukan mendeskripsikan bagian permukaan dari sautu realitas seperti yang dilakukan peneliti kuantitatif dengan positivismenya. ${ }^{83}$ Penelitian lapangan ini dimaksudkan untuk mengetahui eksistensi peran Dinas Sosial Kabupaten Bone dalam menanggulangi kemiskinan perspektif Undang-Undang Nomor 11 Tahun 2009 tentang Kesejahteraan Sosial.

Pendekatan merupakan proses perbuatan, cara mendekati, usaha dalam rangka aktifitas penelitian untuk mengadakan hubungan dengan orang yang diteliti. ${ }^{84}$ Pendekatan yang digunakan dalam penelitian ini

${ }^{82}$ Afrizal, Metode Penelitian Kualitatif (Cet.I; Jakarta: Rajawali Pers, 2014), h. 13

${ }^{83}$ Haris Herdiansyah, Wawancara, observasi, dan Focus Groups sebagai instrumen penggalian data kaulitatif, (Cet.1; Jakarta: Rajawali Pers, 2013), h. 17.

${ }^{84}$ Departemen Pendidikan dan Kebudayaan, Kamus Besar Bahasa Indonesia (Cet. VI; Jakarta: Balai Pustaka, 1995), h. 218.

Jurnal Al-Dustur; VOLUME 2 NO 2, DESEMBER 2019 
56 | Peran Dinas Sosial Kabupaten Bone

adalah pendekatan yuridis-empiris yang diawali dengan penelitian normatif atau penelahaan terhadap peraturan perundang-undangan (normatif) yang dilanjutkan dengan observasi yang mendalam serta penyebarluasan kuesioner untuk mendapatkan data faktor non-hukum yang terkait dan yang berpengaruh terhadap peraturan perundangundangan yang diteliti. ${ }^{85}$ Penelitian hukum empiris yaitu pendekatan dengan melihat suatu kenyataan hukum di dalam masyarakat. ${ }^{86}$ Dalam hal ini peran dinas Sosial dalam menanggulangi kemiskinan. Penelitian hukum normatif dengan cara mengkaji hukum tertulis yang bersifat mengikat dari segala aspek yang kaitannya dengan pokok bahasa yang diteliti.

2. Lokasi Penelitian

Adapun lokasi pelaksanaan penelitian adalah di Kantor Dinas sosial Kabupaten Bone. Kerena Kantor Dinas Sosial Kabupaten Bone merupakan Kantor Dinas yang menangani masalah kemiskinan, baik berupa penanggulangan maupun pemberantasan.

3. Data dan Sumber Data

Data adalah segala keterangan (informasi) mengenai segala hal yang berkaitan dengan tujuan penelitian, akan tetapi tidak segala informasi atau keterangan merupakan data, hanyalah sebagian saja dari

${ }^{85}$ Dayanto, Peraturan Perundang-Undangan Di Indonesia : Konsep Teknik Pembentukannya Berbasis Good Legislation, (Cet. I; Yogyakarta: CV Budi Utama,2018) h. 72

${ }^{86}$ Zainuddin Ali, Metode Penelitian Hukum (Cet.V; Jakarta: Sinar Grafika, 2014), h. 105 
informasi, yakni yang berkaitan dengan penelitian. ${ }^{87}$ Adapun data yang digunakan dalam penelitian ini adalah:

a. Data primer adalah data yang diperoleh langsung dari sumbernya, baik melalui wawancara, observasi maupun laporan dalam bentuk dokumen tidak resmi yang kemudian diolah oleh peneliti. ${ }^{88}$ Data primer yang digunakan dalam penelitian ini yaitu data yang diperoleh secara langsung dari objek yang diteliti baik pribadi (responden) maupun dari suatu instansi yang mengolah data untuk keperluan penelitian, seperti dengan melakukan wawancara secara langsung dengan pihak-pihak yang berhubungan dengan penelitian yang dilakukan.Adapun data primer yang dimaksud oleh peneliti disini yaitu data yang diperoleh langsung dari dinas Sosial Kabupaten Bone.

b. Data sekunder adalah data yang diperoleh dari dokumen-dokumen resmi, buku-buku yang berhubungan dengan objek penelitian, hasil penelitian dalam bentuk laporan, skripsi, tesis, disertasi, dan peraturan perundang-undangan. Data sekunder tersebut, dibagi menjadi tiga, yaitu:

1) Bahan hukum primer yang mengikat terdiri dari peraturan perundang-undangan yang terikat dengan objek penelitian. Bahan hukum primer dalam penelitian ini adalah Undang-

\footnotetext{
${ }^{87}$ Tatang M. Amirin, Menyusun Rencana Penelitian (Cet. III; Jakarta: PT RajaGrafindo Persada, 1995), h. 130.

${ }^{88}$ Zainuddin Ali, Metode Penelitian Hukum, h. 106
} 
58 | Peran Dinas Sosial Kabupaten Bone

Undang Nomor 11 Tahun 2009 tentang Kesejahteraan Sosial.

2) Bahan hukum sekunder yang terdiri dari buku-buku dan tulisan-tulisan ilmiah hukum yang terkait dengan eksistensi peran Dinas Sosial Kabuapten Bone dalam menangggulangi Kemiskinan.

3) Bahan hukum tersier yaitu petunjuk atau penjelasan mengenai bahan hukum primer atau bahan hukum sekunder yang berasal dari kamus, ensiklopedia, majalah, surat kabar, dan sebagainya. ${ }^{89}$

4. Instrumen Penelitian

Instrumen penelitian atau alat pengumpulan data bertujuan untuk menentukan kualitas penelitian, karena itu, alat pengumpulan data harus mendapat penggarapan yang cermat. Lazimnya dalam penelitian dikenal tiga jenis alat pengumpulan data studi dokumen atau bahan pustaka, pengamatan atau observasi, dan wawancara atau interview. ${ }^{90}$ Instrumen yang digunakan dalam penelitian ini yakni Handphone untuk mengambil gambar serta daftar pertanyaan dan alat tulis sebagai pedoman wawancara.

${ }^{89}$ Zainuddin Ali, Metode Penelitian Hukum, h. 106

${ }^{90}$ Amiruddin dan Zainal Asikin, Pengantar Metode Penelitian Hukum, (Cet.II; Jakarta:Raja Grafindo Persada, 2004), h. 65-67. 


\section{Teknik Pengumpulan Data}

Dalam mengumpulkan data peneliti menempuh hal-hal sebagai berikut:

a. Studi Dokumen atau Bahan Pustaka

Studi dokumen merupakan langkah awal dari setiap penelitian hukum (baik normatif maupun sosiologis), studi dokumen bagi penelitian hukum meliputi studi bahan-bahan hukum yang terdiri dari bahan hukum primer, bahan hukum skunder, dan bahan hukum tersier. Setiap bahan hukum ini harus diperiksa ulang validitas dan kredibilitasnya. Sebab, hal ini sangat menentukan hasil suatu penelitian. ${ }^{91}$

b. Wawancara, yaitu (interview) situasi peran antar pribadi bertatap muka (face to face), ketika seseorang yakni pewawancara mengajukan pertanyaan-pertanyaan yang dirancang untuk memperoleh jawaban-jawaban yang relevan dengan masalah penelitian kepada seorang responden. ${ }^{92}$ Wawancara dilakukan dengan pegawai dinas Sosial Kabupaten Bone yakni, Harum A. Hamid, Irfan Judda, dan Akhiruddin. Serta beberapa masyarakat yakni Emma, Hj. Kasnaeni, Murniati, dan Dawiah.

\footnotetext{
${ }^{91}$ Amiruddin dan Zainal Asikin, Pengantar Metode Penelitian Hukum, h. 68

${ }^{92}$ Amiruddin dan Zainal Azikin, Pengantar Metode Penelitian Hukum, h. 82.
} 
60 | Peran Dinas Sosial Kabupaten Bone

\section{HASIL PENELITIAN DAN PEMBAHASAN}

Peran Dinas Sosial dalam Menanggulangi Kemiskinan di Kabupaten Bone Perspektif Undang-Undang Nomor 11 Tahun 2009 tentang Kesejahteraan Sosial

Kemiskinan merupakan masalah sosial yang ada dimasyarakat dan adalah tanggungjawab semua pihak. Peran pemerintah sangat berarti dalam mengurangi kemiskinan karena memiliki kewenangan dan kemampuan hal tersebut. Programprogram pembangunan yang mempunyai sasaran pada penduduk miskin adalah sangat berangam, baik ditinjau dari segi sektor program pembangunan, sektor alokasi anggaran, maupun sektor instansi penyelenggara, pelaksana program, dan penanggungjawab program.

Rencana untuk menanggulangi kemiskinan dan menciptakan lapangan kerja telah dilakukan pemerintah bersama dengan masyarakat melalui pengembangan dan penyelenggaraan berbagai program-program penanggulangan kemiskinan. Programtersebut mencakup upaya-upaya baik melalui penyediaan kebutuhan pangan, layanan kesehatan dan pendidikan, perluasan kesempatan kerja, pembangunan pertanian, pemberian dana bergulir sebagai modal usaha, pembangunan sarana dan prasarana maupun pendapingan usaha. Pemerintah telah berupaya keras untuk menanggulangi kemiskinan dan mengurangi pengangguran. Hal ini diwujudkan melalui pelaksanaan program-program penanggulangan kemiskinan khususnya program berbasis pemberdayaan masyarakat dan program peningkatan kemandirian masyarakat melalui pendapingan usaha dan bantuan kredit/modal kerja. Upaya tersebut juga dapat dilihat dari semakin meningkatnya alokasi anggaran untuk program penanggulangan kemiskinan. ${ }^{93}$

\footnotetext{
${ }^{93}$ Nurmasyitah dan Mislinawati, Upaya Pemerintah dalam Menanggulangi Kemiskinan, Jurnal Pesona Dasar, Vol. 1, No. 5, April 2017, h.34
} 
Kabupaten Bone merupakan salah satu daerah yang memiliki garis kemiskinan masih di atas garis kemiskinan provinsi dan pusat. Berbagai langkah strategis pemerintah daerah untuk mendukung upaya penanggulangan kemiskinan tersebut melalui intervensi program/kegiatan secara terintegrasi antar lembaga pemerintah, swasta dan masyarakat. $^{94}$

Data kemiskinan di Kabupaten Bone pada tahun 2015 sebanyak 60.603, pada tahun 2016 sebanyak 90.759 dan tahun 2017 sebanyak 92.010. dapat dilihat bahwa angka kemiskinan di Kabupaten Bone setiap tahunnya mengalami peningkatan, peningkatan yang paling signifikan terlihat pada tahun 2016, sementara pada tahun 2017 angka kemiskinan di Kabupaten Bone juga mengalami sedikit peningkatan. ${ }^{95}$

Hal tersebut dapat dilihat pada tabel berikut ini:

\begin{tabular}{|c|l|c|c|c|c|}
\hline \multirow{2}{*}{ No } & \multirow{2}{*}{ KECAMATAN } & \multicolumn{3}{|c|}{ TAHUN } & \multirow{2}{*}{ SUMBER DATA } \\
\cline { 3 - 5 } & & $\mathbf{2 0 1 5}$ & $\mathbf{2 0 1 6}$ & $\mathbf{2 0 1 7}$ & \\
\hline 1 & Ajangale & 2.770 & 4.295 & 4.317 & \multirow{2}{*}{ Kememsos Nomor } \\
\cline { 1 - 5 } 2 & Amali & 2.065 & 2.524 & 3.039 & \multirow{2}{*}{$71 / \mathrm{HK} / 2018$} \\
\hline 3 & Awangpone & 2.908 & 4.264 & 4.268 & \\
\hline 4 & Barebbo & 2.170 & 3.407 & 3.461 & \\
\cline { 1 - 5 } 5 & Bengo & 2.445 & 3.900 & 3.928 & \\
\cline { 1 - 4 } 6 & Bontocani & 2.000 & 2.594 & 2.661 & \\
\cline { 1 - 4 } 7 & Cenrana & 2.103 & 3.260 & 3.295 & \\
\hline
\end{tabular}

${ }^{94}$ Harum A.Hamid, Kasubag. Program Dinas Sosial, wawancara oleh penulis di Kantor Dinas Sosial Kabupaten Bone, 9 Oktober 2018

\footnotetext{
${ }^{95}$ Harum A.Hamid, Kasubag. Program Dinas Sosial, wawancara oleh penulis di Kantor Dinas Sosial Kabupaten Bone, 9 Oktober 2018
} 
$62 \mid$ Peran Dinas Sosial Kabupaten Bone

\begin{tabular}{|c|l|c|c|c|}
\hline 8 & Cina & 2.151 & 3.871 & 3.903 \\
\hline 9 & Dua Boccoe & 2.037 & 4.299 & 4.321 \\
\hline 10 & Kahu & 2.794 & 4.029 & 3.949 \\
\hline 11 & Kajuara & 2.561 & 4.620 & 4.640 \\
\hline 12 & Lamuru & 1.858 & 2.495 & 2.537 \\
\hline 13 & Lappariaja & 1.909 & 3.309 & 3.342 \\
\hline 14 & Libureng & 2.651 & 4.818 & 4.697 \\
\hline 15 & Mare & 2.297 & 3.057 & 3.137 \\
\hline 16 & Palakka & 2.642 & 3.420 & 3.435 \\
\hline 17 & Patimpeng & 1.513 & 1.722 & 1.815 \\
\hline 18 & Ponre & 1.642 & 1.985 & 2.000 \\
\hline 19 & Salomekko & 1.644 & 2.304 & 2.379 \\
\hline 20 & Sibulue & 3.234 & 3.711 & 3.824 \\
\hline 21 & Tanete Riattang & 1.325 & 2.898 & 2.924 \\
\hline 22 & $\begin{array}{l}\text { Tanete Riattang } \\
\text { Barat }\end{array}$ & 1.887 & 3.709 & 3.735 \\
\hline 23 & $\begin{array}{l}\text { Tanete Riattang } \\
\text { Timur }\end{array}$ & 2.686 & 3.290 & 3.323 \\
\hline 24 & Tellu Limpoe & 1.879 & 2.298 & 2.314 \\
\hline 25 & Tellu Siattingge & 3.738 & 5.195 & 5.231 \\
\hline 26 & Tonra & 1.292 & 2.021 & 2.035 \\
\hline 27 & Ulaweng & 2.402 & 3.464 & 3.500 \\
\hline & TOTAL & $\mathbf{6 0 . 6 0 3}$ & $\mathbf{9 0 . 7 5 9}$ & $\mathbf{9 2 . 0 1 0}$ \\
\hline & & & \\
\hline
\end{tabular}

Sumber: Dinas Sosial Kabupaten Bone 


\section{Berdasarkan Undang-Undang Nomor 11 Tahun 2009 tentang} Kesejahteraan Sosial peran Dinas Sosial Kabupaten Bone dalam penanggulangan kemiskinan yakni:

1. Meningkatkan kapasitas dan mengembangkan kemampuan dasar serta kemampuan berusaha masyarakat miskin.

Hal ini diatur dalam Peraturan Menteri Sosial Nomor 2 tahun 2019 tentang bantuan sosial usaha ekonomi produktif (UEP) kepada kelompok usaha bersama (KUBE) untuk penanganan fakir miskin. Pemberian usaha ekonomi produktif kepada kelompok usaha bersama bertujuan untuk penguatan kapasitas fakir miskin dalam meningkatkan pendapatan dan kemampuan berusaha sehingga mampu memenuhi kebutuhannya secara mandiri serta meningkatkan kesetiakawanan sosial. ${ }^{96}$

Pembentukan KUBE diajukan oleh kelompok masyarakat kepada dinas sosial daerah kabupaten yang dibantu pendampingan sosial KUBE. Selanjutnya Dinas Sosial kabupaten melakukan verifikasi dan validasi berdasarkan dasar terpadu penanganan fakir miskin dan orang tidak mampu, mengusulkan calon KUBE berdasarkan hasil verifikasi dan validasi kepada menteri sosial. ${ }^{97}$

Namun fakta yang didapatkan dilapangan menunjukkan bahwa progam tersebut tidak terealisasi karena masyarakat tidak mengetahui

\footnotetext{
${ }^{96}$ Republik Indonesia, "Peraturan Menteri Sosial Nomor 2 Tahun 2009 Tentang Bantuan Sosial Usaha Ekonomi Produktif Kepada Kelompok Usaha BersamaUntuk Penanganan Fakir Miskin", Bab I, Pasal 2

${ }^{97}$ Irfan Judda, Kepala Seksi Pendampingan dan Pemberdayaan, wawancara oleh penulis di Kantor Dinas Sosial Kabupaten Bone, 26 Juli 2019
} 
$64 \mid$ Peran Dinas Sosial Kabupaten Bone

adanya aturan mengenai usaha ekonomi produktif kepada kelompok usaha bersama yang dapat dibentuk dengan kriteria mempunyai potensi, kemauan dan kemampuan untuk mengembangkan usaha bersama, mempunyai jenis usaha dan tinggal di wilayah desa, kelurahan atau nama lain dalam kecamatan yang sama dan mempunyai keterbatasan akses terhadap pasar, modal dan usaha.

Hal ini seperti yang dikatakan oleh Emma seorang ibu rumah tangga yang mempunyai usaha sebagai penjual campuran bahwa;

Saya yang ditunjuk sebagai agen untuk menyalurkan bantuan pangan non tunai (beras dan telur) tapi saya tidak mengetahui ternyata saya jadi agen e-warong (elektronik warung gotong royong) kelompok usaha bersama (KUBE) dan saya tidak mengetahui hal yang saya lakukan merupakan kelompok usaha bersama. ${ }^{98}$

Peneliti menilai bahwa program ini belum tepat sasaran karena mayoritas kelompok usaha bersama merupakan orang-orang yang tergolong mampu yang seharusnya menjadi bagian dari kelompok usaha bersama ini yakni orang-orang yang tergolong tidak mampu (miskin).

2. Memperkuat peran masyarakat miskin dalam pengambilan keputusan kebijakan publik yang menjamin penghargaan, perlindungan, dan pemenuhan hak-hak dasar.

Untuk menghasilkan masukan dan presepsi yang berguna dari warga negara dan masyarakat yang berkepentingan dalam rangka meningkatkan kualitas pengambilan keputusan karena dengan melibatkan masyarakat yang potensial terkena dampak akibat kebijakan dan

\footnotetext{
${ }^{98}$ Emma, Ibu Rumah Tangga, Wawancara Oleh Penulis di Sugiale, 27 Juli 2019
} 
kelompok kepentingan, para pengambil keputusan dapat menangkap pandangan, kebutuhan dan pengharapan dari masyarakat dan kelompok tersebut, untuk kemudian menuangkannya dalam suatu konsep.

Upaya peningkatan kemampuan dan partisipasi masyarakat miskin dalam perumusan kebijakan publik dilakukan dengan meningkatkan kemampuan dan akses masyarakat miskin untuk berpartisipasi dalam keseluruhan proses pembangunan, meningkatkan peran serta masyarakat miskin dalam perencanaan, pelaksanaan dan evaluasi atas proyek-proyek pembangunan yang berdampak langsung pada penanggulangan kemiskinan dan menyediakan informasi pembangunan bagi masyarakat miskin baik laki laki dan perempuan. ${ }^{99}$

Berdasarkan hal tersebut peneliti tidak menemukan adanya keterlibatan masyarakat miskin dalam pengambilan keputusan kebijakan publik karena masyarakat miskin dianggap memiliki keterbatasan dalam hal ilmu pengetahuan, masyarakat hanya menerima setiap keputusan yang dibuat oleh pemerintah.

3. Memberikan penyuluhan, bimbingan sosial dan pelayanan sosial

Seperti yang dikatakan oleh Bapak Harum A.Hamid Kasubag Program Dinas Sosial yang mengatakan bahwa telah melakukan bimbingan sosial berupa bimbingan mental dan bimbingan spiritual yang meliputi pemberian bimbingan mental spiritual secara rutin dan berkesinambungan yang diikuti kegiatan ibadah, pelayanan bimbingan

\footnotetext{
${ }^{99}$ Akhiruddin, Kordinator PKS Tenaga Kesejahteraan Sosial, wawancara oleh penulis di Kantor Dinas Sosial Kabupaten Bone, 26 Juli 2019
}

Jurnal Al-Dustur; VOLUME 2 NO 2, DESEMBER 2019 
66 | Peran Dinas Sosial Kabupaten Bone

mental perilaku yang meliputi kegiatan pembinaan berorientasi pada perubahan sikap dan perilaku yang normatif dalam bentuk ceramah, curah pendapat dan lain-lain, pelayanan bimbingan yang meliputi kegiatan pembinaan berorientasi pada pengenelan kegiatan wirausaha, pelayanan bimbingan minat, bakat, dan intelektual yang meliputi kegiatan pembinaan pengembangan potensi diri, intelektual, serta minat dan bakat. $^{100}$

Adapun peran lain yang dilakukan Dinas Sosial kabupaten Bone yakni sebagai fasilitator dalam pemberian Bantuan Pangan Non Tunai (BPNT), bantuan kepada masyarakat lanjut usia, dan bantuan lain seperti Program Keluarga Harapan (PKH), Kartu Indonesia Pintar (KIP) serta Kartu Indonesia Sehat (KIS) yang bekerja sama dengan dinas Pendidikan, dinas kesehatan, Polres Bone, perusahaan daerah (Bulog), aparat desa, pemerintah daerah dan perusahaan lokal lainnya yang peduli masalah kesejahteraan sosial. ${ }^{101}$

Berkaitan dengan program-program tersebut, respon masyarakat yang peneliti dapatkan bahwa dengan adanya bantuan sosial masyarakat sangat terbantu ekonominya. mereka dapat terbantu dalam membiayai anak-anaknya seperti biaya pendidikan dan kesehatan beitupun bantuan pangan non tunai, masyarakat menganggap bahwa bantuan tersebut dapat meringankan kebutuhan pangan masyarakat dalam kehidupan sehari-hari.

${ }^{100}$ Harum A.Hamid, Kasubag. Program Dinas Sosial, wawancara oleh penulis di Kantor Dinas Sosial Kabupaten Bone, 26 Juli 2019

${ }^{101}$ Harum A.Hamid, Kasubag. Program Dinas Sosial, wawancara oleh penulis di Kantor Dinas Sosial Kabupaten Bone, 9 Oktober 2018 


\section{Kendala yang dihadapi Dinas Sosial dalam Menanggulangi Kemiskinan di Kabupaten Bone}

Dinas Sosial kabupaten Bone dalam menanggulangi kemiskinan tidak berjalan dengan baik, karena dalam penanggulangan kemiskinan masih terdapat kendala yang dihadapi diantaranya:

1. Kurangnya anggaran dari pemerintah

Mengatasi masalah kemiskinan sebenarnya bukan perkara yang mudah bagaimanapun masalah kemiskinan belum sepenuhnya bisa diatasi dengan baik karena kurangnya anggaran yang diterima dari pemerintah, karena tidak akan ada program bantuan sosial yang terlaksana tanpa adanya anggaran dan jumlah anggran juga sangat mempengaruhi lancar tidaknya program yang dilaksanakan. Tidak dapat dipungkiri bahwa semua program bantuan sosial yang dilaksanakan oleh Dinas Sosial kabupaten Bone belum bisa mengatasi kemiskinan secara signifikan. Hal ini bukan karena program bantuan sosial yang tidak sesuai tetapi lebih disebabkan oleh kurangnya anggaran sehingga bantuan sosial kepada masyarakat belum merata. ${ }^{102}$

2. Kurangnya Sumber Daya Manusia

Sumber daya manusia merupakan modal kunci untuk menanggulangi kemiskinan. Sumber daya alam yang kurang terlatih merupakan permasalahan, hal ini bisa disebabkan oleh kurangnya kesadaran kita bersama untuk berbagi ilmu dengan sesama. Banyak orang

${ }^{102}$ Harum A.Hamid, Kasubag. Program Dinas Sosial, wawancara oleh penulis di Kantor Dinas Sosial Kabupaten Bone, 26 Juli 2019 
miskin yang tak sanngup menyekolahkan anaknya sehingga linggkaran kemiskinan itu terus terulang kembali ke generasi berikutnya karena tertutupnya keluarga miskin dari pengetahuan yang membawa pembaharuan. Selain itu buruknya fasilitas pendidikan menjadi kendala berarti untuk memperbaiki tingkat pendidikan. Pendidikan adalah cara terbaik untuk membentuk manusia berkualitas yang memiliki kemampuan, karena itu penguatan pendidikan harus dilakukan sebagai langkah untuk menciptakan sumber daya manusia yang tangguh, kompetitif, berdaya juang tinggi dan kreatif. ${ }^{103}$

\section{Tingginya Angka Kemiskinan}

Indonesia merupakan negara yang mempunyai penduduk sangat padat. Dengan jumlah penduduk yang sangat padat membuat Indonesia mengalami masalah sosial salah satunya kemiskinan. Akibat tingginya angka kemiskinan menyebabkan Dinas Sosial kabupaten Bone masih mengalami kesulitan dalam penanggulangan kemiskinan ditambah lagi anggaran yang kurang dari pemerintah sehingga semakin sulit untuk merealisasikan program bantuan sosial kepada masyarakat. ${ }^{104}$

${ }^{103}$ Harum A.Hamid, Kasubag. Program Dinas Sosial, wawancara oleh penulis di Kantor Dinas Sosial Kabupaten Bone, 26 Juli 2019

${ }^{104}$ Harum A.Hamid, Kasubag. Program Dinas Sosial, wawancara oleh penulis di Kantor Dinas Sosial Kabupaten Bone, 26 Juli 2019 


\section{PENUTUP}

\section{Kesimpulan}

Berdasarkan data hasil penelitian dan analisis terhadap rumusan masalah sebelumnya, maka dapat ditarik simpulan sebagai Berikut:

1. Peran Dinas Sosial Dalam menanggulangi kemiskinan Diatur dalam Undang-Undang Nomor 11 Tahun 2009 tentang Kesejahteraan Sosial yakni Meningkatkan kapasitas dan mengembangkan kemampuan dasar serta kemampuan berusaha masyarakat miskin, Memperkuat peran masyarakat miskin dalam pengambilan keputusan kebijakan publik yang menjamin penghargaan, perlindungan, dan pemenuhan hak-hak dasar, memberikan penyuluhan, bimbingan sosial dan pelayanan sosial. Namun, fakta yang didapatkan dilapangan menunjukkan bahwa progam tersebut tidak terealisasikan dengan baik seperti yang diketahui masyarakat tidak mengetahui adanya aturan mengenai usaha ekonomi produktif kepada kelompok usaha bersama yang dapat dibentuk dengan kriteria mempunyai potensi, kemauan dan kemampuan untuk mengembangkan usaha bersama, mempunyai jenis usaha dan tinggal di wilayah desa, kelurahan atau nama lain dalam kecamatan yang sama dan mempunyai keterbatasan akses terhadap pasar, modal dan usaha dan tidak dimukan adanya keterlibatan masyarakat miskin dalam pengambilan keputusan kebijakan publik karena masyarakat miskin dianggap memiliki keterbatasan dalam hal ilmu pengetahuan, masyarakat hanya menerima setiap keputusan yang dibuat oleh pemerintah. 
70 | Peran Dinas Sosial Kabupaten Bone

2. Adapun kendala yang dihadapi Dinas Sosial dalam penanggulangan kemiskinan yakni kurangnya anggaran dari masyarakat, kuran sumber daya manusia dan tingginya angka kemiskinan sehingga penanggulangan kemiskinan tidak terealisasi dengan baik.

\section{DAFTAR REFERENSI}

Afrizal, Metode Penelitian Kualitatif . Cet.I; Jakarta: Rajawali Pers. 2014.

Ali, Zainuddin. Metode Penelitian Hukum. Cet. V; Jakarta: Sinar Grafika, 2014.

Amirin, Tatang M. Menyusun Rencana Penelitian. Cet. III; Jakarta: PT. Raja Grafindo Persada, 1995.

Amiruddin dan Zainal Asikin. Pengantar Metode Penelitian Hukum. Ed. 1. Cet. II; Jakarta: PT RajaGrafindo Persada, 2004.

Arifin Dasril. Peran Dinas Sosial Terhadap Penanggulangan Angka Kemiskinan di Kabupaten Siak (Studi kasus di kecamatan Sei Mandau). Skripsi Program Strata 1 Fakultas Ekonomi dan Ilmu Sosial Universitas Islam Negeri Sultan Syarif Kasim Pekanbaru,2013

Arikunto, Suharsimi. Prosedur Penelitian Suatu Pendekatan Praktik. Cet. XV; Jakarta: Rineka Cipta, 2013

Arikunto, Suharsimi. Prosedur Penelitian. Cet. XII; Jakarta: PT Rineka Cipta, 2002.

Bhinadi, Ardito Penanggulangan Kemiskinan dan Pemberdayaan Masyarakat (studi kasus Daerah Istimewah Yogyakarta).Cet.1; yogyakarta: CV Budi Utama, 2017.

Bone, Geografi dan Iklim dalam https://bone.go.id/2013/04/26/geografi-dan-iklim, diakses 16 Juni 2019.]

Dayanto.Peraturan Perundang-Undangan Di Indonesia : Konsep Teknik Pembentukannya Berbasis Good Legislation. Cet. I; Yogyakarta: CV Budi Utama. 2018.

Departemen Pendidikan dan Kebudayaan. Kamus Besar Bahasa Indonesia. Cet. VI; Jakarta: Balai Pustaka, 1995. 
Gemiharto, Ilham dan Evi Rosfiantika. Tata Kelola Pemerintahan dalam Penanggulangan Kemiskinan Melalui Dana Hibah dan Bantuan Sosial Di Indonesia, Ilmu Politik dan Komunikasi. Vol.7, No.1, Juni, 2017.

Herdiansyah, Haris Wawancara, observasi, dan Focus Groups sebagai instrumen penggalian data kaulitatif. Cet.1; Jakarta: Rajawali Pers, 2013.

https://brainly.co.id/tugas/12586552, diakses 22 september 2018.

Ilmi, Syaiful. Konsep Pengentasan Kemiskinan Perspektif Islam, Al-Maslahah, Vol. 13, No. 1, April 2017.

Kementrian Agama RI. Al-Fattah Al-Qur'an 20 Baris terjemahan.

Khomsan, Ali dkk. Indikator Kemiskinan dan Mengklasifikasi Orang Miskin. cet.1; Jakarta: Fakultas Ekologi manusia IPB bekerja sama dengan Yayasan Pustaka Obor Indonesia, 2015.

Nurmasyitah dan Mislinawati. Upaya Pemerintah dalam Menanggulangi Kemiskinan, Jurnal Pesona Dasar, Vol. 1, No. 5, April 2017

Rencana Kerja Pemerintah Daerah (RKPD) Kabupaten Bone Tahun 2015

Republik Indonesia, "Peraturan Menteri Sosial Nomor 2 Tahun 2009 Tentang Bantuan Sosial Usaha Ekonomi Produktif Kepada Kelompok Usaha BersamaUntuk Penanganan Fakir Miskin”

Republik Indonesia. "Undang-Undang Nomor 11 Tahun 2009 tentang Kesejahteraan Sosial", Bab V, Pasal 29C

Riwayadi, Susilo dan Suci Nur Anisyah. Kamus Lengkap Bahasa Indonesia. tc; Surabaya: Sinar Terang, th.

Salim HS \& Erlies Septiana Nurbani. Penerapan Teori Hukum pada Penelitian Disertasi dan Tesis (Buku Kedua). Cet. I: Jakarta: PT RajaGrafindo Persada, 2014.

Sugiyono. Memahami Penelitian Kualitatif . Cet. VIII; Bandung: Alfabeta, 201's.

Suharto, Edi. Membangun Masyarakat Memberdayakan Rakyat. cet.3; Bandung: PT. Refika Aditama, 2009.

Teguh, Muhammad. Metodologi Penelitian Ekonomi. Cet. II; Jakarta: PT. Raja Grafindo Persada, 2001.

W.Js. Poerwadarminta. Kamus Umum Bahasa Indonesia. Jakarta: PT Balai Pustaka, 2006. 
72 | Peran Dinas Sosial Kabupaten Bone

Wati, Hikmah. Peran Dinas Sosial dalam Penyaluran Bantuan Sosial Sebagai Upaya Penanggulangan Kemiskinan Perkotaan di Provinsi Lampung, Skripsi strata 1 Fakultas Hukum Universitas Lampung Bandar Lampung, 2016 